\title{
The decent living standard for families with school- age children
}

\begin{abstract}
GAR-UM-2019-XI-5.5-8 Grant Interim Report: The decent living standard for families with school-age children aims to complete the first stage of the research project. Stage I includes activities for consulting the official publications of the National Institute of Statistics (NIS), Research Institute for Quality of Life (RIQL) and other sources (Eurostat, European Commission, UNICEF), in order to clarify the objectives, methodology and indicators provided in this research. All these activities allow the identification of indicators, which prepare the development of the next stage of the grant, namely: research methodology; elaboration of the questionnaire for families with school-age children; elaboration of the interview guide for the teacher and pediatrician. The methodology will consist of a questionnaire in which families with school-aged children aged 6-14 from Bucharest will be interviewed in order to establish the consumption basket for this family structure. The selection of the mentioned families will be made on the principle of the "snowball", step by step, until the saturation of the information sought. The methodology will also include an interview guide for teachers (teacher / teacher) that will complete the information regarding the school needs of the children, but also for medical staff (pediatrician / family doctor) that will update the medical needs related to health care and children's hygiene, especially in the new conditions of the pandemic with the Corona virus (Covid-19).
\end{abstract}

Keywords: research grant, standard of life, minimum consumption basket for a decent living, families with school-age children, methodology, indicators
Volume 4 Issue 6 - 2020

\author{
Adina Mihăilescu, Mariana Stanciu, Livia \\ Ștefãnescu, Cristina Humă \\ Research Institute for Quality of Life, Romanian Academy, \\ Romania
}

Correspondence: Adina Mihăilescu, Senior Researcher, Research Institute for Quality of Life, Romanian Academy, Romania, Email adina.mihailescu@yahoo.com

Received: October 13, 2020 | Published: December 31, 2020

\section{Introduction}

GAR-UM-2019-XI-5.5-8 Grant Interim Grant Report: The decent living standard for families with school-age children aims to complete the first stage of the research project.

Stage I includes the following sub-activities:

- Consulting the publications of the National Institute of Statistics;

- Consultation of publications and research within the Quality of Life Research Institute;

- Consultation of publications and research from other official sources (Eurostat, UNICEF etc.) in order to clarify the objectives, methodology and indicators provided in this research. All these activities allow the identification of indicators, which prepare the development of the next stage of the grant, namely:

- Research methodology;

- Elaboration of the questionnaire for families with school-age children;

- Elaboration of the interview guide for the teacher and pediatrician.

The methodology will consist of a questionnaire in which families with school children aged 6-14 years from Bucharest will be interviewed in order to establish the consumption basket for this family structure. The selection of the mentioned families will be made on the principle of the "snowball", step by step, until the saturation of the searched information. The results of the survey in Bucharest will be presented in specialized publications, but also in national and international scientific communications. The methodology will also include an interview guide for teachers who will complete the information regarding the school needs of the children, but also for medical staff (pediatrician / family doctor) who will update the medical needs related to health care and children's hygiene, especially in the new conditions of the pandemic with the Corona virus (Covid-19).

\section{Methodology and problem identification}

From the specialized literature and from the discussions carried out in the field in the exploratory phase of the research, with the families with dependent children aged between 6 and 14 years, several problems have been identified that they face:

- financial problems, respectively insufficient income to support their children;

- related to the registration with the family doctor and the provision of a quality medical assistance;

- lack of housing or insufficient space for families with several children, especially if they are of different sexes;

- increasing the value of the allowance due to children from 150 lei per month which covers a small part of the children's consumption needs;

- the fate of children whose parents go to work abroad and remain in the care of grandparents, other relatives or neighbors.

Based on the identified problems, the working tools were built, in order to carry out the field research, our option being that of a quantitative and qualitative approach. We opted for field research by applying structured interviews, aiming to reveal the perspective of the population, but also of the institutional actors on the mentioned problems.

We chose for the field research the Municipality of Bucharest following, as much as possible, a balanced distribution, both from a 
socio-economic point of view, and as a manifestation of some of the phenomena identified in the preliminary documentation phase.

The working tools, the questionnaire and the interview guides were necessary, necessary for the investigation of the social and institutional actors. Regarding the social actors, the statistical population from which we chose the working sample was represented by the families with children from Bucharest, sectors 2, 3, 4 and 6.

\section{Construction and testing of working tools}

In order to achieve the objectives of the project were built:

1. A questionnaire that was applied to 166 families with school-age children; The questionnaire included 30 questions that deal with the following aspects of the life of these families: accessibility to children's education, access to a job for parents, the possibility of affirming in life of parents, the extent to which parents' rights are respected, security of at home and at work, social assistance received from the state; the main problems faced by families with children: poverty, lack of money, lack of schooling, misery and infectious diseases, health problems of parents, quality of social assistance received by children, health problems of children, lack of adequate housing, tensions in the family, environmental pollution, finding a job; what are the monthly expenses with the children, by types of expenses; family income; family worries about the problems of daily life; the importance of school in educating your children; children's free time concerns; followed by identification data of the respective family.

2. An interview guide for teachers or leaders who could learn about children's problems, which includes: common children's problems; forms of support for such cases in your school; form of support for such cases in your school; parents' shortcomings in their responsibility to educate their children; the school has the power to alleviate the problems / deficit of family education; if there have been significant changes in the social behavior of children with parents abroad.

3. An interview guide addressed to the doctor with the following issues: what kind of specific health problems do families face with children in the age groups (6-10 years; 11-14 years); diseases of children who have social causes; other concrete ways to improve the quality of children's care.

The assessments of the extent to which income provides them with a decent living were diverse, reflecting the wide social range of the sample investigated. In some cases decent living has been assimilated to subsistence, given that they say they can ensure a decent living and at the same time respond that they manage to buy only for the child everything that is needed, but many of these needs remain unmet, such as leaving. somewhere on vacation, a weekend getaway, etc. On the other hand, the state should increase allowances. One problem that some families face is that of the consequences of one or both parents leaving for work abroad. The lack of parents is felt quite acutely by children, they are deprived of their love and protection. Some parents make up for this with the material part they provide. Most of the time this benefit is not enough. Students have a completely different picture of life. Parents make money but those who lose are children. ${ }^{1-5}$

\section{Consultation of specialized publications}

\section{NIS publications}

In the period 2008-2019, the resident population aged 0-14 years registered a continuous decrease of the share in the total population representing on January 1, 2019, $15.6 \%$ (16.4\% of the male population and $14.9 \%$ of the female population). As can be seen in Table 1 , in the 11 years of analysis, the population aged $0-4$ years and 5-9 years did not experience significant changes, remaining around 5-5.5\%. Changes in the sense of decreasing the share of children are observed in large age groups 10-14 years and 15-19 years. A decrease of 9\% and even more registers the last group of 15-19 years. The decreases were significantly higher in the male population than in the female population. In the 10-14 age group, the decrease remains at $5 \%$ of the total for the female population and $6 \%$ for the male population.

Table I Romania, the structure of the resident population aged 0-19 years, on 1.01 .2008 and $2019 p$

\begin{tabular}{lllllll}
\hline \multirow{2}{*}{$\begin{array}{l}\text { Age } \\
\text { groups }\end{array}$} & \multicolumn{2}{l}{ Total (\%) } & \multicolumn{2}{l}{ Male (\%) } & \multicolumn{2}{l}{ Female (\%) } \\
\cline { 2 - 7 } & $\mathbf{2 0 0 8}$ & $\mathbf{2 0 1 9}$ & $\mathbf{2 0 0 8}$ & $\mathbf{2 0 1 9}$ & $\mathbf{2 0 0 8}$ & $\mathbf{2 0 1 9}$ \\
\hline Total & 100 & 100 & 100 & 100 & 100 & 100 \\
0-4 years & 5.1 & 5.1 & 5.4 & 5.3 & 4.9 & 4.8 \\
5-9 years & 5.2 & 5.1 & 5.5 & 5.4 & 5 & 4.9 \\
10-14 years & 6 & 5.5 & 6.3 & 5.7 & 5.7 & 5.2 \\
15-19 years & 6.3 & 5.4 & 6.6 & 5.6 & 6 & 5.1 \\
\hline
\end{tabular}

Source: NIS, 2019, Social Trends'. Note: p - for 2019, the data are provisional.

\section{RIQL publications and research}

Research Institute for Quality of Life has conducted research to substantiate a minimum consumption basket for a decent standard of living. The results of this research call into question the resources needed for the Romanian population to live, not so much due to the renewal of the older concept of minimum consumption basket, but especially due to the explicit emphasis on the notion of decent living standards and the expenses to be covered, to be able to ensure such a standard of living. The minimum consumption basket for a decent standard is estimated on a monthly basis for the needs of a family of two adults and two children. The family lives in urban areas, adults are both employees with below average incomes and ages between 35 and 45 years. We also assumed that one of the children is between 12 and 14 years old and the other between 8 and 10 years old. The group interviews were attended by between 8-12 employees from several sectors of activity. The topics of discussion included: the definition of decent living, the main categories of expenditure that the families of the participants have, the necessary level of access to goods and services to achieve a decent standard of living, and the necessary quality of these goods and services. During the interviews, participants were asked to complete questionnaires to estimate the quantitative values for decent consumption in the categories: food, household products and personal hygiene, clothing and apparel, services. The questionnaires proposed lists of preliminary products and services, based on the results of previous RIQL research, but also offered respondents the opportunity to introduce other products and services considered necessary to ensure a decent living. Group interviews were a primary source of information for estimating the content and value of the minimum consumption basket. The results obtained from them were verified with experts (especially in the food and health chapters), corroborated with international standards (in the food chapters, household products and personal hygiene, health), with the results of recent research in Romania (in the chapter education and culture) and, where possible, correlated with the objective needs estimated by the research team (in chapters such as housing, housing, 
housing expenditure). The structure of the minimum consumption basket for a decent living resulting from the research comprises 11 chapters: (1) food, (2) clothing and footwear, (3) housing, (4) housing equipment, (5) housing expenditure, (6) products household and personal hygiene, (7) services, (8) education and culture, (9) health, (10) recreation an d vacation, (11) family savings fund. ${ }^{6-8}$

\section{Collecting prices to calculate the value of the minimum consumption basket for a decent living}

Prices were collected for the main food, non-food products (clothing, footwear, school supplies for children) and services (housing, health, meaning through these services the costs of medicines and were also taken into account the costs of personal care, haircut girl and boy), in order to establish a decent minimum consumption basket for children: by sex of children, as well as by age groups (7-10, 11-14 years), to see how these family expenditures are differentiated. Food prices were picked from the local markets most frequently visited by respondents. In terms of clothing, footwear and school supplies, the prices from the shops identified by the population as those with the most customers in the respective locality were taken over. Housing and medicine expenditures were set as an average amount spent by these families with children, as they said in the interview. It was found that there are no differences in food and non-food items taken into account between the strict expenses of food, clothing, footwear, housing, medicines, children's supplies between families with children of different ages, in the city and near the city.

\section{The concept of decent living}

We defined the minimum decent living as the situation in which the general biological and social needs at a given moment are covered. Decent living can be described as a situation in which a family can afford a balanced, healthy diet without compromising on product quality; he can buy new clothes and shoes from specialty stores and he can renew his wardrobe taking into account wear and tear; has a home that provides shelter and security and that allows a certain degree of privacy and autonomy to family members, is furnished and equipped with quality appliances, in good working order; can easily pay his current bills (maintenance, energy, water, telephone, etc.); can maintain the home and has sufficient means to procure sufficient personal hygiene products for a healthy life, a necessary condition for the psychological comfort and for the social life of the individual; can provide each member with an adequate level of health care, which depends on preventive health services that may or may not be covered by public social security systems; can provide children with good conditions for cognitive, emotional, social and physical development, depending both on the quality of formal education and on participation in extracurricular activities appropriate to their age and expectations; can offer its members the opportunity to recreate and spend their free time together outside the home (going out to the cafe, cinema, museum, etc.), as well as the opportunity to go on vacation at least once a year; can provide its members with the means of mobility and communication necessary for active participation in community life; can enable adults to benefit from lifelong learning, social, cultural, artistic or sporting activities dedicated to them; can set up a savings fund to be able to procure expensive durable goods (for example, the advance on the purchase of housing) or to cover occasional or unforeseen extraordinary expenses, including to be able to help loved ones in case of need. ${ }^{9,10}$

\section{Other publications and research}

The total number of households in the European Union increased between 2017 - 2018 from 220 to over 222 million. But the number of households with children has fallen, from 65.4 million (about a third of the total number of households) to almost 65.1 million. This attests to the tendency to reduce the number of household members, but also to reduce the birth rate in some countries. Of the EU Member States, Ireland has the highest proportion of households with children $(40 \%)$ in total households, ahead of Cyprus and Poland (both with $37 \%$ each), Slovakia (36\%), Portugal and Romania (both). by 35\% each). The lowest shares of households with children are registered in Germany and Finland (both by 22\%), followed by Bulgaria (25\%), Austria (26\%) and Sweden (27\%). In 2018, at EU level, almost half of all households with children (47\% ie around 31 million households) had only one child, while $40 \%$ (26 million) had two children and $13 \%$ (8.5 million) had three or more children (Table 2).

Table 2 Weights of households with children in the European Union in 2018

\begin{tabular}{lllll}
\hline Year & Households with one child & Households with two children & Households with three children & Of which single parents \\
\hline 2017 & $47 \%$ & $40 \%$ & $13 \%$ & $15 \%$ \\
\hline
\end{tabular}

Source: Eurostat, 2017, Number of private households by household composition. ${ }^{2}$

In 2018, there were approximately 222.8 million households in the European Union (Table 3). Almost a third (65 million) of them had children in their care.

In 2017 , about $16.9 \%$ of the total population and about $34.2 \%$ of single people with dependent children were at risk of poverty in EU28 countries. In 2018, the highest share of children at risk of poverty or social exclusion was registered in Romania (38.1\%), at a European

Table 3 Households with dependent children in the EU28 (thousand), in 2018 (data updated on 05.03.2020)

\begin{tabular}{lll}
\hline & Total households & Households with dependent children \\
\hline EU.28 & 222818.7 & 65076.0 \\
Belgium & 4770.4 & 1521.3 \\
Bulgaria & 2708.0 & 715.7 \\
\hline
\end{tabular}

average of $23.4 \%$.

In both 2017 and 2018, in EU-28 countries, the most common situations of social risk were among single people with dependent children. Very high shares of poor families with three or more children were registered in Romania (61.9\% in 2017) or in Bulgaria (65\% in 2017) (Table 4). 
Table continued..

\begin{tabular}{|c|c|c|}
\hline & Total households & Households with dependent children \\
\hline R.Czech & 4759.8 & | 482.6 \\
\hline Denmark & 2402.2 & 699.3 \\
\hline Germany & 40806.6 & 8897.4 \\
\hline Estonia & 610.9 & 188.9 \\
\hline Ireland & I 842.0 & 719.3 \\
\hline Greece & 4383.6 & I 186.7 \\
\hline Spain & 18580.6 & 6240.0 \\
\hline France & 29778.2 & 9142.6 \\
\hline Croatia & I 473.6 & 497.9 \\
\hline Italy & 25925.8 & 7603.6 \\
\hline Cyprus & 326.8 & 116.3 \\
\hline Latvia & 854.3 & 252.5 \\
\hline Lithuania & I 321.7 & 373.6 \\
\hline Luxembourg & 251.5 & 85.3 \\
\hline Hungary & $4 \mid 24.8$ & I 191.9 \\
\hline Malta & 192.4 & 63.4 \\
\hline Netherlands & 7834.2 & 2182.4 \\
\hline Austria & 3915.5 & 992.9 \\
\hline Poland & 14608.9 & 5330.4 \\
\hline Portugal & $4 \mid 44.6$ & | 407.2 \\
\hline Romania & 7494.3 & 2594.5 \\
\hline Slovenia & 887.1 & 271.3 \\
\hline Slovakia & | 888.4 & 671.1 \\
\hline Finland & 2677.1 & 584.3 \\
\hline Sweden & 5239 & 1181.6 \\
\hline Great Britain & 29015.8 & 8881.9 \\
\hline
\end{tabular}

Source: Eurostat, 2020, Number of private households by household composition. ${ }^{3}$

Table 4 Poverty rate by types of households, in EU countries.28, in 2017

\begin{tabular}{llll}
\hline Country & Total population rate & $\begin{array}{l}\text { Single people with dependent } \\
\text { children }\end{array}$ & $\begin{array}{l}\text { Two adults with three or more } \\
\text { dependent children }\end{array}$ \\
\hline EU.28 & 16.9 & 34.2 & 26.2 \\
Belgium & 16.0 & 39.7 & 19.1 \\
Bulgaria & 23.4 & 35.7 & 65.0 \\
R. Czech & 9.1 & 31.4 & 17.4 \\
Denmark & 12.4 & 23.7 & 8.9 \\
Germany & 16.1 & 33.2 & 19.5 \\
Estonia & 21.9 & 28.9 & 19.5 \\
Ireland & 15.6 & 44.1 & 19.1 \\
Greece & 20.2 & 30.3 & 24.4 \\
Spain & 21.6 & 40.6 & 43.9 \\
France & 13.1 & 32.6 & 26.3 \\
Croatia & 20.0 & 37.2 & 31.3 \\
Italy & 20.3 & 37.8 & 37.1 \\
Cyprus & 15.7 & 25.2 & 17.5 \\
\hline
\end{tabular}


Table continued...

\begin{tabular}{llll}
\hline Country & Total population rate & $\begin{array}{l}\text { Single people with dependent } \\
\text { children }\end{array}$ & $\begin{array}{l}\text { Two adults with three or more } \\
\text { dependent children }\end{array}$ \\
\hline Latvia & 22.2 & 34.3 & 19.8 \\
Lithuania & 22.9 & 48.4 & 44.3 \\
Luxembourg & 18.7 & 46.2 & 26.7 \\
Hungary & 13.3 & 31.2 & 14.2 \\
Malta & 16.7 & 42.9 & 35.5 \\
Netherlands & 13.2 & 35.7 & 16.2 \\
Austria & 14.4 & 31.4 & 26.8 \\
Poland & 14.9 & 23.3 & 14.7 \\
Portugal & 18.3 & 33.1 & 41.4 \\
Romania & 23.6 & 31.2 & 61.9 \\
Slovenia & 13.3 & 30.0 & 13.4 \\
Slovakia & 12.4 & 37.3 & 35.4 \\
Finland & 11.5 & 19.5 & 12.3 \\
Sweden & 15.7 & 36.0 & 20.4 \\
M. Britain & 17.0 & 39.8 & 31.1 \\
\hline
\end{tabular}

Source: Eurostat, 2019, Quality of life indicators. ${ }^{5}$

In 2018, approximately $23.4 \%$ of children in the EU-28 were at risk of poverty and social exclusion compared to $22.1 \%$ of adults (18-64) and $18.4 \%$ of the elderly (65 years and over). The factors influencing the risk of poverty or social exclusion were:

- type of household - single parents with dependent children (42.8\%), single people $(31.7 \%)$ and families of two adults with three or more dependent children $(27.6 \%)$ had the highest poverty rates and social exclusion.

- monetary poverty: $73.4 \%$ of the population aged between 0 and 59 , living in households with very low labor intensity, with dependent children, lived at risk of poverty.

- level of education: $51.5 \%$ of children whose parents' level of education was low, lived at risk of poverty, compared to $7.4 \%$ of children with parents with a high level of education.

- emigration history: children with a family emigration environment had a higher risk of poverty than children with native parents $(33.7 \%$ compared to $16.2 \%$ ).

- family structure: $11.6 \%$ of single-parent households were severely deprived of material, compared to $6.2 \%$ of all households with dependent children

In general, in 2018, children (aged 0 to 17) with at least one parent born abroad had a 17.5 percentage point (pp) higher risk of poverty than children with native parents. The largest differences between children with foreign parents versus natives were recorded in Belgium $(+28.5 \mathrm{pp})$, Spain $(+29.5 \mathrm{pp})$, Sweden $(+29.9 \mathrm{pp})$ and France $(+$ $30.3 \mathrm{pp})$. ). The highest rates of poverty and social exclusion for Table 5 Children included in the public services of early education and care, 2017 (\%)

\begin{tabular}{|c|c|c|c|c|}
\hline & \multicolumn{2}{|c|}{ Children between 0 și 3 years } & \multicolumn{2}{|c|}{ Children over 3 years } \\
\hline & Romania & EU Media & Romania & EU Media \\
\hline Full - time children of early education and care & $1.7 \%$ & $17.2 \%$ & $12.1 \%$ & $49.9 \%$ \\
\hline Part-time children of early education and care & $14 \%$ & $17 \%$ & $47.7 \%$ & $34.9 \%$ \\
\hline Children cared for only by parents & $41 \%$ & $46.1 \%$ & $12.8 \%$ & $9.6 \%$ \\
\hline
\end{tabular}

Source: European Commission, 2019, Employment, Social Affairs \& Inclusion Country profiles - Romania: Policies and progress towards investing in children, https://ec.europa.eu/social/main.jsp?catld=| 248\&langld=en\&int Pageld $=3654 .{ }^{8}$

children with at least one parent born abroad were recorded in Spain (49.2\%), France (43.6\%) and Italy (40.2\%), while the lowest rate was observed in the Czech Republic (10.5\%). In some EU Member States, immigrant parents have not experienced higher poverty rates than their native population. Latvia, Portugal and Lithuania ( $-5.6 \mathrm{pp},-4.2$ pp and -1.3 pp) were the only Member States of the European Union, where children with at least one parent born abroad had a more visible level, lower the risk rate of poverty than the children of native parents.

\section{Material deprivation at the level of households with children in the EU}

In $2018,11.6 \%$ of children living in single-parent families with dependent children in the EU were severely deprived of material goods, compared to $6.2 \%$ living in households with dependent children.

Households of two adults with two dependent children (4.0\%) had a slightly lower risk than households of two adults with one dependent child $(4.1 \%)$. For children living in households of two adults with three or more dependent children, the share was $6.6 \%$.

\section{Risk categories targeting some of the children living in Romania}

Almost 4 million children live in Romania. Although significant progress has been made in the area of social welfare in the last 30 years, a large proportion of children are still affected by poverty, lack of health services at the local level, and lack of quality education (Table 5). 
Half of children in Romania live at risk of poverty and social exclusion, and 1 in 4 suffer from severe material deprivation (Eurostat, 2017). Around 400,000 children are constantly left out of the public education system, thus gaining a low chance of finding a job when they reach adulthood (UNICEF study, 2017). More than 52,000 children become separated from their families as a result of poverty, violence or neglect. Every year, 10,000 children are separated from their parents. One million children are hospitalized each year. Such hospitalizations could be prevented by providing local primary medical services. In 2018, more than 15,000 cases of abused, neglected and exploited children were reported (statistics published by the National Authority for the Rights of the Child and Adoption). The most vulnerable children are those from poor families, Roma communities, rural areas and children with disabilities.
According to a study conducted by UNICEF, each additional year spent on school benches increases the income of the future adult by $8-9 \%$, reduces the risk of unemployment by $8 \%$ and the risk of serious health problems by $8.2 \%$ (UNICEF, 2020, For each child...) [9]. As of 31 December 2018, of the 109,279,876 children and adolescents living in EU countries, 3,487,701 (4\%) were born outside the EU (Table 6). Of the 3,487,701 children born outside the EU, 25\% were $5-9$ years old, $30 \%$ were $10-14$ years old, and $46 \%$ were $15-19$ years old. Most of the school-age children born outside the EU were hosted by Germany (688 669), the United Kingdom (569 308), France (555 192), Spain (492 520), Italy (389 180) and Sweden (215 601).

Table 6 School-age children migrants or refugees seeking asylum in European countries (data for the period 20I5-20I8)

\begin{tabular}{|c|c|c|}
\hline Country & Number of refugees and migrants of school age & Share of the total number of children in that country \\
\hline Germany & 688669 & $5 \%$ \\
\hline Great Britain & 569308 & $4 \%$ \\
\hline France & 555192 & $4 \%$ \\
\hline Spain & 492520 & $5 \%$ \\
\hline Italy & 389180 & $4 \%$ \\
\hline Sweden & 215601 & $9 \%$ \\
\hline Netherlands & 143170 & $4 \%$ \\
\hline Belgium & 105252 & $4 \%$ \\
\hline Austria & 99237 & $6 \%$ \\
\hline Switzerland & 90012 & $5 \%$ \\
\hline Greece & 83567 & $4 \%$ \\
\hline Norway & 73747 & $6 \%$ \\
\hline Poland & 67109 & $1 \%$ \\
\hline Romania & 63086 & $2 \%$ \\
\hline Denmark & 54511 & $4 \%$ \\
\hline Portugal & $4766 I$ & $2 \%$ \\
\hline Ireland & 39215 & $3 \%$ \\
\hline Finland & 33492 & $3 \%$ \\
\hline Hungary & 28848 & $2 \%$ \\
\hline R.Czech & 24671 & $1 \%$ \\
\hline Bulgaria & 18593 & $2 \%$ \\
\hline Slovenia & 15006 & $4 \%$ \\
\hline Luxembourg & 7913 & $6 \%$ \\
\hline Cyprus & 7840 & $4 \%$ \\
\hline Croatia & 7442 & $1 \%$ \\
\hline Slovakia & 5251 & $0.40 \%$ \\
\hline Lithuania & 5094 & $1 \%$ \\
\hline Malta & 4470 & $5 \%$ \\
\hline Estonia & 3964 & $1 \%$ \\
\hline Liechtenstein & 3551 & $5 \%$ \\
\hline Latvia & 3313 & $0.80 \%$ \\
\hline Iceland & 2801 & $3 \%$ \\
\hline
\end{tabular}

Source: UNHCR-UNICEF-IOM, 2019,Access to education for refugee and migrant children in Europe, September I0. 


\section{Education}

It is a key element for the social inclusion of refugee or immigrant children in host communities. European countries affected by the refugee and immigrant crisis of 2015-2016 have made efforts to ensure that children have access to school as much as possible. In Bulgaria, Greece and Serbia, for example, between $50 \%$ and $62 \%$ of school-age refugee children and immigrant children have been integrated into the formal education system since December 2018.

\section{Living conditions}

Low quality housing is usually associated with a low level of material well-being. There are several objective aspects that can be a basis for assessing living conditions in the EU, for example, housing deficiencies (damp walls or roof leaks), overcrowding or lack of basic facilities (a toilet, shower or bathtub). . The share of the European population living in overcrowded housing in 2017 was the highest in Romania, where the lowest share of the population living in underoccupied housing was also recorded. In $2017,15.7 \%$ of the EU population lived in overcrowded housing, while about two-fifths (36.4\%) lived in underoccupied housing (Eurostat, 2019, Quality of life indicators ....). ${ }^{11}$

Some of these differences between EU Member States reflect social habits and changes, in particular related to the importance of family ties and the growing percentage of people living alone; between 2007 and 2017, the share of EU-28 households consisting of one or two people increased from $58 \%$ to $62 \%$. In rural areas of southern and eastern Europe, larger families continue to live together under the same roof. In thirteen EU Member States, less than a tenth of the population lived in an overcrowded household in 2017, with a share of less than $4.0 \%$ in Cyprus, Ireland, Malta and the United Kingdom. At the other end of the range, overcrowding affects over $40.0 \%$ of the population in Hungary, Poland, Bulgaria and Latvia reaching a maximum of $47.0 \%$ in Romania.

\section{Acknowledgments}

None.

\section{Conflicts of interest}

The autors declare no conflicts o interest.

\section{Funding}

Research grant made with financial support from the Recurrent Donors Fund, available to the Romanian Academy and managed by the „PATRIMONIU” Foundation GAR-UM-2019.

\section{References}

1. NIS. Social Trends. 2019.

2. Eurostat. Number of private households by household composition, number of children and age of youngest child (1000). 2017.

3. Eurostat. Number of private households by household composition, number of children and age of youngest child (1000). 2020.

4. Eurostat, 2018, Children at risk of poverty or social exclusion, 2018, (percentage of children aged less than 18 years), Eurostat:

5. Eurostat. Quality of life indicators - material living conditions, Statistics explained, File: Overcrowding rate and proportion of the population living in under occupied housing, 2017. 2019.

6. Eurostat. Children at risk of poverty rate, by country of birth of their parents -2018 , (Share of children $<18$ years) Eurostat. 2018.

7. Eurostat. Severe material deprivation rate, by household type - 2018, (Share of total population), Eurostat (ilc_mddd13). 2018.

8. European Commission. Employment, Social Affairs \& InclusionCountry profiles - Romania: Policies and progress towards investing in children. 2019.

9. UNICEF, 2020, Pentru fiecare copil.

10. UNHCR-UNICEF-IOM. Access to education for refugee and migrant children in Europe. 2019.

11. Eurostat, 2019. Quality of life indicators - material living conditions, Statistics explained, File: Overcrowding rate and proportion of the population living in under occupied housing, 2017. 